\title{
The effect of $\beta$-glucanase on the nutritive value of hulless barley cv. Rastik for broiler chickens*
}

\author{
M. Bekta ${ }^{1,3}$, M. Fabijańska ${ }^{1}$ and S. Smulikowska ${ }^{2}$ \\ ${ }^{1}$ Warsaw Agricultural University, Department of Animal Nutrition and Feed Science \\ Ciszewskiego 8, 02-786 Warsaw, Poland \\ ${ }^{2}$ The Kielanowski Institute of Animal Physiology and Nutrition, \\ Polish Academy of Sciences \\ 05-110 Jabłonna, Poland
}

\begin{abstract}
The experiment was carried out on 48 eight-day-old broiler females, kept in individual cages and allocated to 3 groups, 16 birds per group. Two experimental diets were formulated, both contained $800 \mathrm{~g} / \mathrm{kg}$ of hulless barley cv. Rastik, and were unsupplemented or supplemented with a $\beta$-glucanase preparation (Avizyme 1100, $1.5 \mathrm{~g} / \mathrm{kg}$ ). The control diet was based on wheat and soyabean meal and was supplemented with a xylanase preparation. All diets contained $210 \mathrm{~g}$ crude protein $/ \mathrm{kg}$. The diets were fed for 2 weeks, in the third week 6 chickens from each group were killed and digesta were collected from different parts of the digestive tract for viscosity measurements. The apparent metabolizable energy (AME) of barley was measured in a balance experiment done on 10 birds from each group.

Supplementation of the barley diet with $\beta$-glucanase increased feed intake by $9 \%(\mathrm{P}<0.01)$ and body weight gain by $3.7 \%$ and significantly decreased $(\mathrm{P}<0.01)$ the viscosity of digesta, except in the crop and caeca. In the group fed the unsupplemented barley diet, viscosity equaled 1.37, 3.46, 3.93 and $4.78 \mathrm{mPas} \cdot \mathrm{s}$ in the digesta from the stomach, jejunum, ileum and caeca, respectively, in the group fed the barley diet with $\beta$-glucanase, $0.86,2.33,2.91$ and 21.55 , respectively, while in the control group, 1.01, 1.34, 1.64 and 4.24, respectively. Supplementation with $\beta$-glucanase increased the AME value of barley from 10.8 to $13.1 \mathrm{MJ} / \mathrm{kg}(\mathrm{P}<0.01)$.
\end{abstract}

KEY WORDS: hulless barley, $\beta$-glucanase, viscosity, metabolizable energy, broiler chickens

\section{INTRODUCTION}

Hulless forms of barley contain more digestible nutrients than hulled barley cultivars due to lower contents of undigestible fibre fractions, but they also

\footnotetext{
* Supported by the State Committee for Scientific Research, Grant No. 2 P06Z 03926

${ }^{3}$ Corresponding author: e-mail: bekta@bydlo.com.pl
} 
contain also more $\beta$-glucans (Boros et al., 1996). Scott et al. (1998) reported that the apparent metabolizable energy (AME) of hulless barley cultivars measured on broiler chickens was even lower than of hulled ones, but increased greatly after $\beta$-glucanase supplementation. The objective of this study was to determine the effect of supplementing Polish hulless barley cv. Rastic with $\beta$-glucanase on the viscosity of digesta and AME in broiler chickens.

\section{MATERIAL AND METHODS}

Hulless barley cv. Rastik grown at the Breeding Station in Radzików in 2002 was used in the experiment. The chemical composition of barley was determined by standard methods, total and water-soluble $\beta$-glucans, according to Åman and Graham (1987). The in vitro viscosity of barley and wheat was determined as follows: finely ground grain was mixed 9:1 (w/w) with distilled water or $0.1 \mathrm{M} \mathrm{KCl} /$ $\mathrm{HCl}$ buffer ( $\mathrm{pH} 1.5$ ), extracted for $1 \mathrm{~h}$ at $25^{\circ} \mathrm{C}$, centrifuged at $1000 \mathrm{~g}$ for $10 \mathrm{~min}$. The viscosity of the supernatants was measured with a Brookfields Viscometer (Model LVDV II+).

Forty-eight 8-day-old broiler females were divided into 3 groups, 16 birds per group, and were kept in individual cages in an environmentally controlled room. Two experimental diets were designed according to Scott et al. (1998) and contained, $\mathrm{g} / \mathrm{kg}$ : hulless barley cv. Rastik 800 , casein 50 , isolated soya protein 50 , rapeseed oil 30, limestone 13, dicalcium phosphate $13, \mathrm{NaCl} 3$, mineral-vitamin premix 5, L-lysine (78\%) 1, DL-methionine (98\%) 2.1 and wheat starch or $\beta$-glucanase preparation (Avizyme 1100, Finnfeeds Int.) 1.5. The wheat- and soyabean mealbased control diet was supplemented with $1 \mathrm{~g} / \mathrm{kg}$ xylanase (Avizyme 1300, Finnfeeds Int.). All diets contained $210 \mathrm{~g} \mathrm{CP} / \mathrm{kg}$, an antibiotic growth promoter (Avilamycin), and were cold pelleted. Birds were given the diets and water ad libitum. Feed intake and body weight were measured for 2 weeks.

At the start of the third week of the study, six birds from each group were sacrificed and their intestinal tracts excised. Digesta from the crop, stomach, jejunum, ileum and caeca was collected (that from the caeca was mixed 1:1w/w with water), centrifuged at $10000 \mathrm{~g}$ for $10 \mathrm{~min}$, and the viscosity of the supernatants was measured with a Brookfields Viscometer (Model LVDV II+). Ten birds from both experimental groups received the same diets with a marker $\left(3 \mathrm{~g} \mathrm{Cr}_{2} \mathrm{O}_{3}\right.$ per $\mathrm{kg}$ diet). After two days of a preliminary period excreta were collected quantitatively from each bird for four days and frozen at $-18^{\circ} \mathrm{C}$ until analysis. Diets and excreta were dried, ground and analysed for $\mathrm{DM}, \mathrm{Cr}_{2} \mathrm{O}_{3}$, total and faecal nitrogen, crude fat and gross energy as described by Mieczkowska et al. (2004). The digestibility coefficients of the diets and AME value of barley were calculated according to Scott et al. (1998). Data were analysed by one-way analysis of variance using Statgraphics Plus ver. 5.1. 


\section{RESULTS}

The hulless barley grain contained, $\%$ of DM: crude protein 14.9 , total $\beta$-glucans 3.6 (soluble 1.3, insoluble 2.3). The in vitro viscosity of a water extract of barley was 0.96 , acid extract $3.07 \mathrm{mPas} \cdot \mathrm{s}$. The respective in vitro viscosity values for wheat $\mathrm{cv}$. Corveta used in control diet were 0.83 and $0.87 \mathrm{mPas} \cdot \mathrm{s}$.

Table 1. Performance (day 8-21 of life) and viscosity of digesta (mPas $\cdot \mathbf{S}) \pm \mathrm{SD}$

\begin{tabular}{|c|c|c|c|}
\hline \multirow{2}{*}{ Item } & \multicolumn{3}{|c|}{ Dietary treatment } \\
\hline & control + xylanase & barley & barley $+\beta$-glucanase \\
\hline Feed intake, $g$ & $1060^{\mathrm{A}} \pm 111$ & $971^{\mathrm{B}} \pm 81$ & $1060^{\mathrm{A}} \pm 105$ \\
\hline Body weight gain, $g$ & $763^{\mathrm{A}} \pm 70$ & $664^{\mathrm{B}} \pm 43$ & $689^{\mathrm{B}} \pm 66$ \\
\hline FCR, g feed/g BWG & $1.39^{\mathrm{A}} \pm 0.12$ & $1.46^{\mathrm{B}} \pm 0.56$ & $1.48^{\mathrm{B}} \pm 0.59$ \\
\hline \multicolumn{4}{|c|}{ Viscosity of digesta, $\mathrm{mPas} \cdot \mathrm{s}$} \\
\hline crop & $1.57 \pm 0.44$ & $1.55 \pm 0.43$ & $1.45 \pm 0.77$ \\
\hline stomach & $1.01^{\mathrm{AB}} \pm 0.34$ & $1.37^{\mathrm{A}} \pm 0.43$ & $0.86^{\mathrm{B}} \pm 0.21$ \\
\hline jejunum & $1.34^{\mathrm{A}} \pm 0.33$ & $3.46^{\mathrm{C}} \pm 1.08$ & $2.33^{\mathrm{B}} \pm 0.43$ \\
\hline ileum & $1.64^{\mathrm{A}} \pm 0.27$ & $3.93^{\mathrm{C}} \pm 1.38$ & $2.91^{\mathrm{B}} \pm 0.66$ \\
\hline caeca $^{1}$ & $4.24^{\mathrm{A}} \pm 3.06$ & $4.78^{\mathrm{A}} \pm 4.41$ & $21.55^{\mathrm{B}} \pm 16.7$ \\
\hline
\end{tabular}

1 mixed 1:1 w/W with distilled water; ${ }^{\mathrm{A}, \mathrm{B}}$ means in rows with different superscripts were significantly different at $\mathrm{P}<0.01$

The performance of birds fed hulless barley diets was lower than of controls. Feed intake increased significantly $(\mathrm{P}<0.01)$ and body weight gain numerically (by 3.7\%) after supplementation of the barley diet with $\beta$-glucanase (Table 1). Supplementation with $\beta$-glucanase significantly affected $(\mathrm{P}<0.01)$ the viscosity of digesta. Crop digesta viscosity did not differ among groups, that of the stomach, jejunal and ileal digesta was significantly higher in the group fed unsupplemented barley than in the control- and barley-supplemented groups. The viscosity of caecal digesta was similar in the control and barley groups, and four times higher in the group fed barley supplemented with $\beta$-glucanase (Table 1 ).

Apparent protein digestibility and nitrogen retention were similar in chickens fed the unsupplemented or supplemented barley diets, while apparent fat digestibility increased by 6 percentage points and the apparent metabolizable energy of barley increased by $2.3 \mathrm{MJ} / \mathrm{kg}$ in response to $\beta$-glucanase supplementation (Table 2).

Table 2. Results of balance experiment \pm SD

\begin{tabular}{lrc}
\hline \multirow{2}{*}{ Item } & \multicolumn{2}{c}{ Dietary treatment } \\
\cline { 2 - 3 } & \multicolumn{1}{c}{ barley } & barley $+\beta$-glucanase \\
\hline Apparent protein digestibility (diet), \% & $87.8 \pm 1.3$ & $88.9 \pm 1.3$ \\
Nitrogen retention (diet), \% & $55.1 \pm 4.2$ & $58.7 \pm 4.8$ \\
Apparent fat digestibility (diet), \% & $88.1^{\mathrm{A}} \pm 3.0$ & $94.0^{\mathrm{B}} \pm 1.4$ \\
Metabolizable energy (barley), MJ/kg DM & $10.8^{\mathrm{A}} \pm 1.5$ & $13.1^{\mathrm{B}} \pm 0.6$ \\
\hline
\end{tabular}

${ }_{\mathrm{A}, \mathrm{B}}$ means in rows with different superscripts were significantly different at $\mathrm{P}<0.01$ 


\section{DISCUSSION}

Hulless barley cv. Rastik had a similar crude protein content as found previously for three lines of hulless barley by Boros et al. (1996), but its $\beta$-glucan content was lower. In the present study, stomach and small intestinal digesta viscosity was higher, and feed intake lower, in the group fed the unsupplemented hulless barley diet in comparison with the control. The viscosity of stomach and small intestinal digesta decreased, and feed intake increased, after supplementation of the barley diet with $\beta$-glucanase. Chaplin et al. (1992) reported that intraduodenal infusion of hyperosmotic solutions decreased feed intake in turkeys and might involve a decrease in gastrointestinal motility. Chesson (2001) showed that $\beta$-glucanase readily cleaved some bonds within $\beta$-glucans, resulting in a mixture of gluco-oligosacharides with lower viscoelastic properties, positively affecting digestion and absorption in the small intestine of broiler chickens. The results of the present study indicate that fat digestion was most affected, as it was 6 percentage points higher in $\beta$-glucanase supplemented chickens.

The AME of barley cv. Rastik was $10.8 \mathrm{MJ} / \mathrm{kg} \mathrm{DM}$ and increased by $21 \%$ after $\beta$-glucanase supplementation. Scott et al. (1998) reported a value of $12.1 \mathrm{MJ} / \mathrm{kg}$ for hulless barley of Canadian origin and found a $14 \%$ increase after $\beta$-glucanase supplementation. In our study, caecal digesta viscosity in the unsupplemented barley group was comparable with control values, while in the $\beta$-glucanase supplemented group, it was significantly higher $(\mathrm{P}<0.01)$. This supports our previous observations (Mieczkowska et al., 2004) that partial cleavage of plant non-starch polysaccharides by added enzymes increases the viscosity of caecal contents.

\section{CONCLUSIONS}

$\beta$-glucanase supplementation of hulless barley increases its nutritive value for broiler chickens.

\section{REFERENCES}

Åman P., Graham H., 1987. Analysis of total and insoluble mixed-linked (1-3) (1-4) $\beta$-D-glucans in barley and oats. J. Agr. Food Chem. 35, 704-709

Boros D., Rek-Ciepły B., Cyran M., 1996. A note on the composition and nutritional value of hulless barley. J. Anim. Feed Sci. 5, 417-424

Chaplin S.B., Raven J., Duke G.E., 1992. The influence of the stomach on crop function and feeding behavior in domestic turkeys. Physiol. Behav. 52, 261-266

Chesson A., 2001. Non-starch polysaccharide degrading enzymes in poultry diets: influence of ingredients on the selection of activities. World Poultry Sci. J. 57, 251-263

Scott A., Silversides F.G., Classen H.L., Swift M.L., Bedford M.R., Hall J.W., 1998. Broiler chick bioassay for measuring the feeding value of wheat and barley in complete diets. Poultry Sci. 77, 449-455

Mieczkowska A., Smulikowska S., Nguyen C.V., 2004. Effect of enzyme supplementation of white lupin (Lupinus albus var. Butan) -containing diets on performance, nutrient digestibility, viscosity, $\mathrm{pH}$ and passage rate of digesta in broiler chickens. J. Anim. Feed Sci. 13, 475-486

Statgraphics ${ }^{\circledR}$ ver. 5.1., 1994-2001. Statistical Graphic System by Statistical Graphic Corp. 